\title{
DO MANDATO SEM REPRESENTAÇÃO DE PORTUGAL
}

\author{
ON THE MANDATE WITHOUT REPRESENTATION FROM PORTUGAL
}

\author{
Pedro Linhares Della Nina ${ }^{1}$
}

\begin{abstract}
Resumo: Este trabalho tem como objetivo apresentar o instituto do mandato sem representação, previsto no direito português (Código Civil Português, materializado no Decreto-Lei n. ${ }^{\circ}$ 47.344, de 25/11/1966, que revogou o Código de Seabra), traçando paralelo com a procuração em causa própria do direito brasileiro (Código Civil Brasileiro, decorrente de um projeto de 1969, coordenado por Miguel Reale, que foi transformando, muitos anos depois, na Lei n. ${ }^{\circ}$ 10.406, de 10/01/2002, tendo revogado o Código Beviláqua), sempre com cotejo dos artigos legislativos envolvidos e à luz da doutrina especializada dos 2 (dois) países.O ensejo da pesquisa é cotejar os dois tratamentos dados à matéria, posto que ambos proporcionam garantias aos contratantes, enfrentando as diferenças existentes de forma direta e abordando as principais considerações doutrinárias/jurisprudenciais sobre o tema.
\end{abstract}

Palavras-chaves: Direito Civil; Procuração em Causa Própria; Mandato sem Representação.

\begin{abstract}
This paper presents the institute called the mandate without representation of Portuguese law (the Portuguese Civil Code - Decree-Law n. ${ }^{0}$ 47.344/1966 - which repealed the Seabra Code), drawing a parallel with the "procuração em causa própria" of Brazilian Law (the Brazilian Civil Code, resulting from a 1969 project, coordinated by Miguel Reale, which was transformed many years later into Law n. ${ }^{\circ} 10.406 / 2002$, having repealed the Beviláqua Code), comparing the legislative articles and transcribing the specialized doctrine of the 2 (two) countries. The research opportunity is to compare the two treatments given to the matter, since both provide guarantees to the contractors, facing the existing differences directly and addressing the main doctrinal / jurisprudential considerations on the subject.
\end{abstract}

Keywords: Civil Law; Power of Attorney; Mandate without Representation.

\section{Introdução}

O presente trabalho, ainda que em parcas palavras, tem o escopo de apresentar o contrato denominado Mandato sem Representação, previsto nos artigos 1.180 ao 1.184, do Código Civil Português (Secção VI, do Capítulo X [Mandato], do Título II [Dos Contratos em Especial], do Livro II [Direito das Obrigações]), a seguir transcritos:

\author{
SECÇÃO VI \\ Mandato sem representação \\ ARTIGO 1180 \\ (Mandatário que age em nome próprio)
}

\footnotetext{
1 Advogado e Professor da Universidade Candido Mendes/RJ, mestre em Ciências Jurídicas pelo UAL-Lisboa, pós-graduado em Direito Empresarial e em Litigation, ambos pela FGV-Rio de Janeiro; email: pedro.linhares@jucaelinhares.com.br
} 
O mandatário, se agir em nome próprio, adquire os direitos e assume as obrigações decorrentes dos actos que celebra, embora o mandato seja conhecido dos terceiros que participem nos actos ou sejam destinatários destes.

\section{ARTIGO 1181 ${ }^{\circ}$}

(Direitos adquiridos em execução do mandato)

1. O mandatário é obrigado a transferir para o mandante os direitos adquiridos em execução do mandato.

2. Relativamente aos créditos, o mandante pode substituir-se ao mandatário no exercício dos respectivos direitos.

ARTIGO 1182

(Obrigações contraídas em execução do mandato)

$\mathrm{O}$ mandante deve assumir, por qualquer das formas indicadas no $\mathrm{n} .^{\circ} 1$ do artigo $595^{\circ}$, as obrigações contraídas pelo mandatário em execução do mandato; se não puder fazê-lo, deve entregar ao mandatário os meios necessários para as cumprir ou reembolsá-lo do que este houver despendido nesse cumprimento.

\section{ARTIGO $1183^{\circ}$}

(Responsabilidade do mandatário)

Salvo estipulação em contrário, o mandatário não é responsável pela falta de cumprimento das obrigações assumidas pelas pessoas com quem haja contratado, a não ser que no momento da celebração do contrato conhecesse ou devesse conhecer a insolvência delas.

\footnotetext{
ARTIGO 1184

(Responsabilidade dos bens adquiridos pelo mandatário)

Os bens que o mandatário haja adquirido em execução do mandato e devam ser transferidos para o mandante nos termos do n. ${ }^{\circ} 1$ do artigo $1181^{\circ}$ não respondem pelas obrigações daquele, desde que o mandato conste de documento anterior à data da penhora desses bens e não tenha sido feito o registo da aquisição, quando esta esteja sujeita a registo.
}

Todavia, antes de adentrar no thema, é de se rememorar as noções conceituais clássicas dos atos jurídicos e dos negócios jurídicos, essenciais para compreender a relevância do que se deseja expor.

\section{Necessária explicação - o negócio jurídico}

Os fatos, em verdade, são a base motivadora de eventos que podem ser jurígenos, isto é, com relevância ao direito, ou não, quer dizer, irrelevantes juridicamente. Paulo Nader, com propriedade, assevera que:

"Em sua gênese, os direitos subjetivos estão ligados a acontecimentos do mundo fático. Na base de cada direito individualizado, está o fato, não qualquer um, mas o que apresenta relevância do ponto de vista social e que por isto é referido no Direito objetivo. Não há direito subjetivo que não se origine de um fato jurídico. Os acontecimentos, indistintamente, considerados, que geram direitos subjetivos são chamados, em sentido amplo, 
de fatos jurídicos ou fatos jurígenos. Estes podem ser definidos como acontecimentos, oriundos da determinação humana ou de fatos naturais, que geram, modificam, conservam ou extinguem relações jurídicas." 2

Manuel A. Domingues de Andrade, adentrando na definição de fato, reconhece que:

"vem a ser todo o facto da vida real juridicamente indiferente, isto é, a que a ordem jurídica não liga quaisquer consequências [...] São, portanto, factos juridicamente irrelevantes, factos destituídos de eficácia jurídica, factos neutrais, sob o ponto de vista do direito - factos ajurídicos, em suma"3.

Fabio Ulhoa Coelho, com o seu viés empresarial no Direto Civil, auxilia no que seria fato jurídico, eis que:

"O fato descrito em norma jurídica como pressuposto da consequência por ela imputada é chamado de fato jurídico. Matar alguém, praticar negócio jurídico com dolo, o possuidor de boa-fé introduzir benfeitorias úteis na coisa e a violação culposa de direitos são exemplos de fatos jurídicos. Note-se que nem todos os fatos têm relevância para o direito. Os eventos são inócuos, sob o ponto de vista jurídico, quando não desencadeiam nenhuma consequência. Se alguém caminha pela praia numa bela manhã de sol, isto é um fato que, em princípio, nada tem de jurídico."4

Assim, sem maiores delongas, é perfeitamente possível classificar o fato da seguinte forma:

Fig. 1 - Fato, Ato e Negócio Jurídico

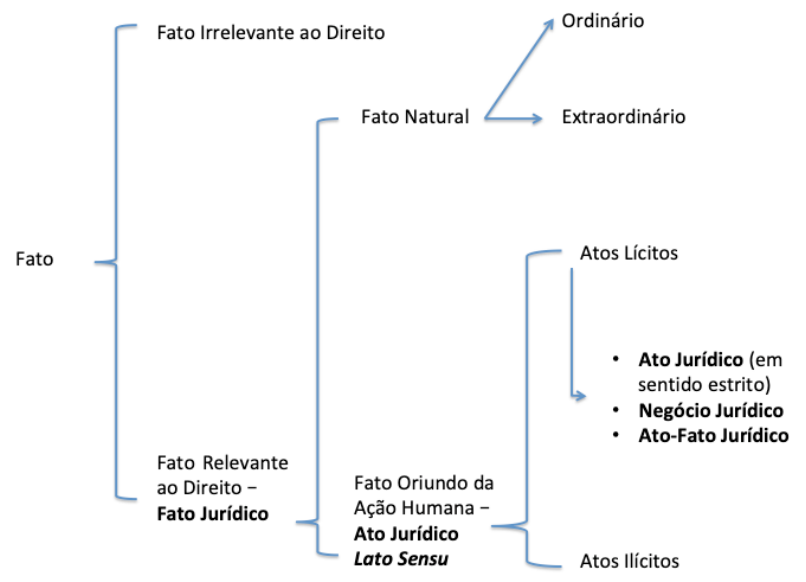

Fonte: DELLA NINA, Pedro Linhares (2020)

Por óbvio, os fatos naturais (aqueles de origem não humana) têm relevo ao direito, seja na passagem de um dia (lapso necessário a que o agente adquira a maioridade ou, quiçá, o

\footnotetext{
${ }^{2}$ NADER, Paulo - Curso de Direito Civil Vol. 1. 10a ed. Rio de Janeiro: Forense, 2016, pag. 363.

${ }^{3}$ DOMINGUES DE ANDRADE, Manuel A. - Teoria Geral da Relação Jurídica - vol. 1. $1^{\text {a }}$ ed. Coimbra: Almedina, 1983, pag. 27.

${ }^{4}$ COELHO, Fabio Ulhoa - Curso de Direito Civil Parte Geral - Vol. 1. $8^{\text {a }}$ ed. São Paulo: Revista dos Tribunais, 2016, pag. 286.
} 
último dia de um prazo judicial), seja em eventos não previsíveis (tempestade e/ou nevasca que causa atraso em voo, maxidesvalorização cambial ${ }^{5}$, entre outros exemplos).

Os fatos que são originários de ação humana são denominados atos jurídicos, sendo subdivididos em ilícitos e lícitos. Vale o registro, importante principalmente ao estudante de graduação, que, no Direito Civil, ato ilícito não é aquele tipificado no código penal, mas sim todo e qualquer descumprimento à norma e ao pactuado. Assim, um descumprimento contratual ${ }^{5}$ Há diversos precedentes interessantes sobre a consequência jurídica de diversas desvalorizações cambiais que
houve na história recente. Como destaque, segue julgado do Superior Tribunal de Justiça sobre venda de
helicópteros, verbis:

"ADMINISTRATIVO. LICITAÇÃO. CONTRATO E ADITIVO PARA FORNECIMENTO DE SEIS HELICÓPTEROS PARA A POLÍCIA RODOVIÁRIA FEDERAL. PREÇO AJUSTADO EM MOEDA NACIONAL (REAL). VENCEDORA CONTRATANTE QUE NECESSITAVA IMPORTAR AS AERONAVES PAGANDO EM MOEDA ESTRANGEIRA (DÓLAR). DESVALORIZAÇÃO DO CÂMBIO OCORRIDA EM JANEIRO DE 1999. TEORIA DA IMPREVISÃO. ÁLEA EXTRAORDINÁRIA CONFIGURADA. REEQUILÍBRIO ECONÔMICO-FINANCEIRO. ART. 65, II, 'D', DA LEI No 8.666/93. INDENIZAÇÃO DEVIDA. RECURSO DA EMPRESA PARTICULAR PROVIDO.

1. Em consonância com o estabelecido no art. 37, XXI, da Constituição Federal, que garante a manutenção das condições efetivas da proposta de contrato celebrado com a Administração, a Lei de Licitações prevê a possibilidade de revisão contratual com o fito de preservação da equação econômica da avença, podendo essa correção, dentre outras premissas, advir da teoria da imprevisão, a teor do disposto no art. 65, II, d, da Lei no 8.666/93.

2. De outro lado, os contratos que tenham por objeto a prestação de serviço firmados em real e executados no exterior, eventualmente submetidos a variação cambial significativa e inesperada, são passiveis de repactuação, conforme previsão do art. 65, inciso II, $d$, da Lei 8.666/1993, caso constatada a oneração excessiva, com o rompimento da equação econômico-financeira firmada.

3. No caso concreto, a empresa autora, ora recorrente, requer indenização pecuniária, mediante a revisão de contrato administrativo para o fornecimento de helicópteros (por ela entregues) destinados ao serviço de remoção de vítimas de acidentes, resgates e operações especiais do Departamento da Polícia Rodoviária Federal, com preço originariamente fixado em moeda nacional (real), ante a alegada quebra da equação econômico-financeira, decorrente da forte desvalorização da moeda brasileira frente ao dólar, fenômeno ocorrido em janeiro de 1999, como consequência da mudança de política cambial então implementada pelo Banco Central.

4. Uma vez demonstrado que as aeronaves necessitavam ser adquiridas pela licitante vencedora no exterior, com o desembolso em dólar realizado logo após a mencionada e drástica alteração da política cambial (passando-se do sistema de bandas para o de livre flutuação do dólar), fato esse que, à época, não poderia ser previsto e que acabou por onerar sobremaneira a empresa recorrente, configurada resulta a álea econômica extraordinária e extracontratual de que trata o art. 65, II, $d$, da Lei no 8.666/93, legitimando a indenização por ela pleiteada.

5. Como já decidido por esta Primeira Turma do STJ no RMS 15.154/PE, Rel. Ministro Luiz Fux, j. 19/11/2002, "O episódio ocorrido em janeiro de 1999, consubstanciado na súbita desvalorização da moeda nacional (real) frente ao dólar norte-americano, configurou causa excepcional de mutabilidade dos contratos administrativos, com vistas à manutenção do equilibrio econômico-financeiro das partes".

6. Recurso especial conhecido e provido. "

(Recurso Especial n. ${ }^{\circ} 1.433 .434$, da $1^{\mathrm{a}}$ Turma do STJ, relatado pelo Ministro Sérgio Kukina, julgado em 20/02/2018 e com acórdão publicado em 21/03/2018). 
é um ilícito, da mesma forma que é apropriar-se de bem móvel que tenha proprietário (definido ou não $\left.{ }^{6}\right)$.

Mais uma vez, Fabio Ulhoa Coelho presta os necessários esclarecimentos:

"Os fatos podem ser condutas humanas, ou não. O caminhar de namorados pela praia e chover são eventos verificados na realidade, mas só o primeiro é ação de seres humanos. De modo algo similar, os fatos jurídicos também podem ser condutas de sujeitos de direito, ou não. Celebrar contrato (isto é, emitir declarações de vontade convergentes) é fato jurídico que representa necessariamente uma ação de pessoas. Completar 18 anos, ao contrário, é fato jurídico que impede de qualquer conduta imputável a um sujeito de direito. Basta o planeta Terra percorrer sua trajetória em torno do sol dezoito vezes depois do nascimento de alguém para que essa pessoa passe a ser considerada capaz pelo direito. Esse fato jurídico caracteriza-se sem que qualquer sujeito - incluindo o aniversariante - tenha de fazer ou deixar de fazer qualquer coisa." 7

Insta ainda demonstrar que os atos jurídicos, ou melhor, os fatos jurígenos causados pela ação humana lícita podem ser registrados como ato jurídico e negócio jurídico. Poder-se-ia utilizar todo o espaço do presente trabalho para efetuar a distinção entre os institutos, mas, para fins objetivos (e por característica do autor), convém diferenciá-los acerca de seus efeitos.

$\mathrm{O}$ ato jurídico tem, por força da norma, efeitos cogentes obrigatórios. Logo, ao realizar o ato, se há a previsão da consequência, sem qualquer ingerência ou modulação pelo agente, tratase de um ato jurídico. Em oposição, se é possível controlar os efeitos da ação, verifica-se um negócio jurídico ${ }^{8}$.

Assim, a renúncia à propriedade ou o reconhecimento de um filho são atos jurídicos em sentido estrito, eis que os efeitos estão claramente previstos na norma (no primeiro caso, o bem se tornará res nullius; enquanto no segundo, não há como reconhecer a paternidade e impedir a utilização do nome ou se excluir de pagar alimentos). Paulo Nader assim se pronuncia:

\footnotetext{
${ }^{6}$ Há um lamentável brocardo no Brasil, no sentido de que "achado não é roubado", o que é uma excrescência jurídica. Há tipo penal previsto no art. 169, do Código Penal Brasileiro, sendo que o descobridor deve entregar a coisa à autoridade policial, à luz do art. 746, do Código de Processo Civil/BR.

${ }^{7}$ COELHO, Fabio Ulhoa - Curso de Direito Civil Parte Geral - Vol. 1. $8^{\mathrm{a}}$ ed. São Paulo: Revista dos Tribunais, 2016, pag. 287.

${ }^{8}$ Há, ainda, a figura do ato-fato jurídico que, em suma, analisa a consequência do ato, não o agente que o realizou. Ainda que não haja ensejo para maiores debates, convém destacar a lição de Carlos Roberto Gonçalves:

"Essas ações são denominadas pela doutrina atos-fatos jurídicos, expressão divulgada no Brasil por Pontes de Miranda. No ato-fato jurídico ressalta-se a consequência do ato, o fato resultante, sem se levar em consideração a vontade de praticá-lo. Assim, por exemplo, não se considera nula a compra de um doce ou sorvete feita por criança de sete ou oito anos de idade, malgrado não tenha ela capacidade para emitir a vontade qualificada que se exige nos contratos de compra e venda. Em se tratando de ato dotado de ampla aceitação social, deve ser enquadrado na noção de ato-fato jurídico."

GONÇALVES, Carlos Roberto - Direito Civil. Brasileiro vol. 1 - Parte Geral. $6^{a}$ ed. São Paulo: Editora Saraiva, 2018, pag. 305
} 
"Enquanto os efeitos dos atos jurídicos stricto sensu são os definidos no ordenamento (ex lege), os relativos aos negócios jurídicos são os estabelecidos pelas partes envolvidas (ex volante), dentro dos limites admitidos pela ordem jurídica." 9

Sobre os negócios jurídicos ${ }^{10}$, cujos efeitos jurídicos podem ser mitigados e controlados, sempre haverá a suscitação de vontade, com ao menos um declarante expressando o seu querer ${ }^{11}$

\footnotetext{
${ }^{9}$ NADER, Paulo - Curso de Direito Civil Vol. 1. 10 ed. Rio de Janeiro: Forense, 2016, pag. 371.

${ }^{10}$ É de se observar, ainda que na presente nota de rodapé, que a autonomia da vontade e o viés privatista do negócio jurídico representam verdadeiros pilares estruturais do direito clássico e, especialmente, do estadunidense, tanto é que estão esculpidas na simples e objetiva Constituição Americana de 1.789, exatamente no art. $1^{\circ}$, Seção 10, item 1, que cria a vedação impositiva de se desequilibrar obrigações contratuais, verbis:

Article. I. - The Legislative Branch

(...)

Section 10 - Powers prohibited of States

No State shall enter into any Treaty, Alliance, or Confederation; grant Letters of Marque and Reprisal; coin Money; emit Bills of Credit; make any Thing but gold and silver Coin a Tender in Payment of Debts; pass any Bill of Attainder, ex post facto Law, or Law impairing the Obligation of Contracts, or grant any Title of Nobility.

(...)
}

A partir dos anos 70, a noção de publicização ${ }^{10}$ do direito contratual ganha força nos Estados Unidos, com a queda da liberdade contratual e da autonomia da vontade, seguido do declínio do dogma da vontade das partes, mitigando a "sanctity of contract". O que se vê é a afetação do Direito dos Contratos, a partir de imposições da ordem pública, do poder de polícia, da defesa dos bons costumes, das imposições "protetivas" (Direito do Trabalho, a legislação antitruste, entre outras), sempre almejando manter a estrutura normativa e o bom andamento do Welfare State.

Os contratos, à luz desse entendimento que busca reduzir o alcance da interpretação clássica, apresentam-se menos como uma livre construção da vontade humana, devendo respeitar e contribuir com a atividade dos agentes econômicos à arquitetura geral da economia definida pelo Estado contemporâneo, dando novos pesos e valores à noção de dirigismo Contratual.

Esse é o cerne do trabalho de Grant Gilmore que, em seu jocoso "Death of Contract", não quis criar uma ode ao descumprimento das obrigações ou alardear para o desuso das figuras contratuais, tampouco estimular os desfazimentos de pacto pré-constituídos. Ao revés, o autor quis celebrar a vida do contrato, com a mudança dos paradigmas tradicionais e a superação da visão clássica, que só serviam de antolhos, causando a cegueira da excessiva valoração da literalidade da letra fria do pacto.

O Ministro aposentado do Supremo Tribunal Federal, Eros Roberto Grau, cuja genialidade é sentida na corte constitucional brasileira, é brilhante ao resumir o thema em dois parágrafos:

"Esse discurso, no entanto, em todas as suas versões, mas especialmente naquela produzida pelos norte-americanos, em sua origem desde quando se passa a falar na morte do contrato (Gilmore) é, na verdade, um discurso a favor da vida do contrato, na medida em que propõe a superação daquela teoria. $O$ mesmo se pode dizer em relação à queda da liberdade Contratual, clamando por um a nova teoria dos contratos, como já queria Atiyah no final dos anos 70. Em todas essas exposições, mostra-se justamente o poder de sobrevivência do contrato, que continua embasando o sistema econômico na medida em que se transforma: declínio do dogma da vontade das partes, de um lado, ascensão dos "contratos fato", como veremos adiante. Mas, sempre e acima de tudo, avenças ( = vínculos jurídicos) que proporcionam a fluência das relações de mercado.

À "morte do contrato" corresponde o fim da teoria clássica, que, na dicção de Guido Alpa, cede ante a necessidade da análise dos interesses concretos que o acordo entre as partes expressa, análise conduzida não segundo o método formal, mas mediante o exame dos interesses substanciais - ao que corresponde a objetivação $e$ despersonalização do contrato."

(GRAU, Eros Roberto - Um Novo Paradigma dos Contratos?. Público [Em linha]. $\begin{array}{lllll}\text { [Consult. } & 30 & \text { outubro. } & 2020] & \text { Disponível }\end{array}$ http://www.revistas.usp.br/rfdusp/article/view/67510)

${ }^{11}$ Aquele que manifesta a sua vontade é denominado declarante; em contrapartida, aquele que a recebe, é tido como declaratário. 
motivador do pacto. Logo, convém apresentar a principal classificação dos negócios jurídicos, relativa ao número de manifestações de vontade expressadas:

Fig. 2 - Classificação do Negócio Jurídico

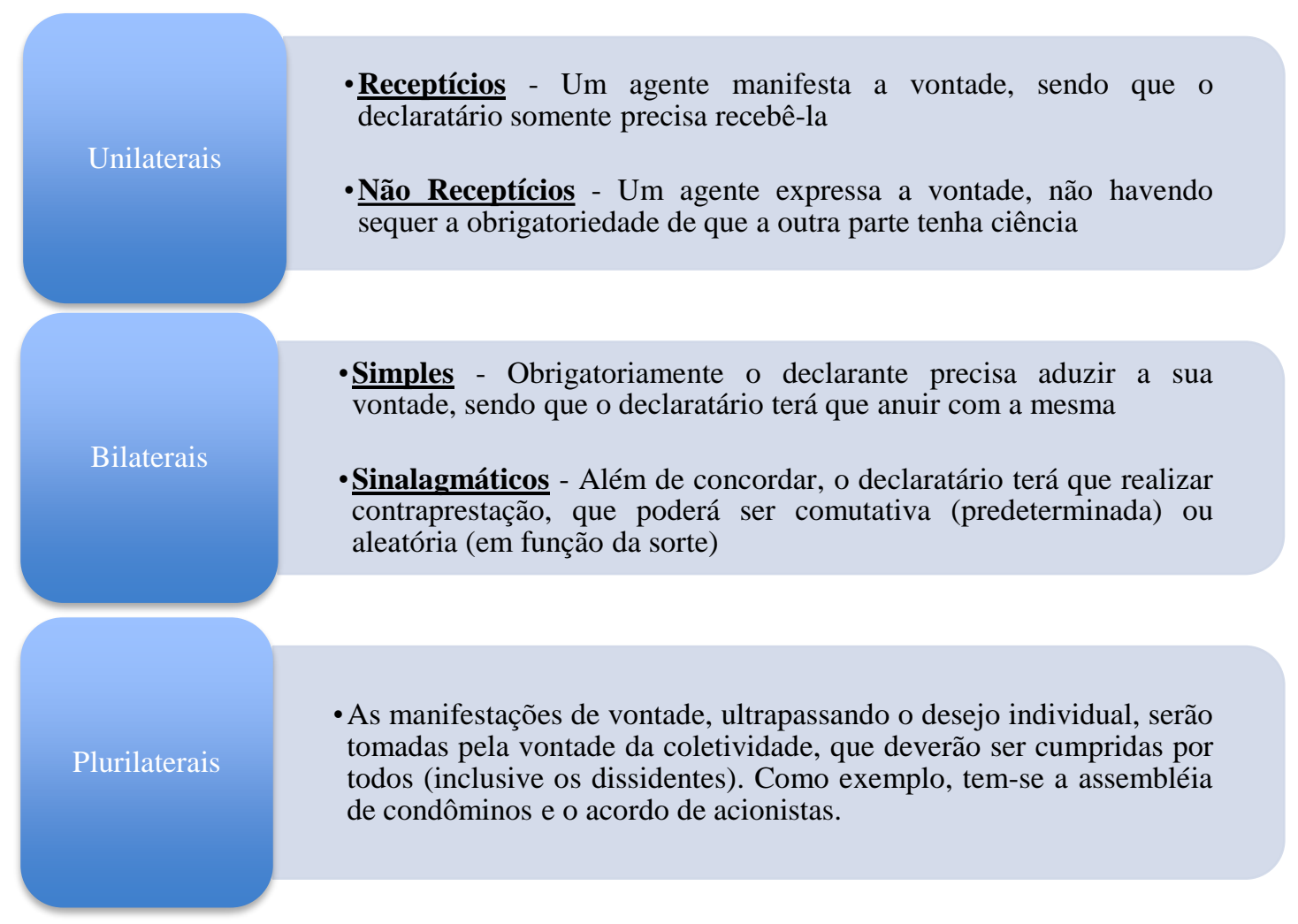

Fonte: DELLA NINA, Pedro Linhares (2020)

Há, ainda, outra relevante classificação de negócios jurídicos acerca do cunho retributivo, isto é:

Fig. 3 - Classificação do Negócio Jurídico pela Vantagem

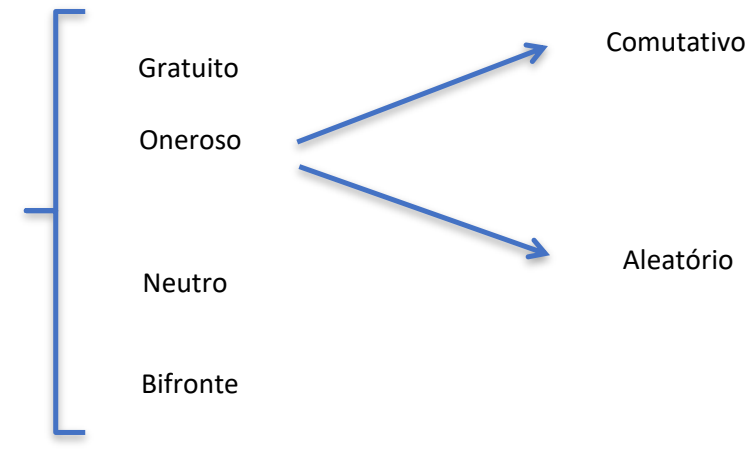

Fonte: DELLA NINA, Pedro Linhares (2020) 
Vê-se, assim, que a despeito do número de manifestações de vontades, os negócios jurídicos também podem ser classificados a partir da existência, ou não, de contraprestação. Tem-se, dessa forma, gratuidade quando houver um agir do contratante, sem qualquer tipo de contrapartida, o que pode se verificar no negócio bilateral simples e no unilateral (receptício ou não-receptício).

Já no negócio oneroso, não se exige eventual proporção nas parcelas, mas sim é imperioso que exista o sinalagma, ou melhor, a presença de reciprocidade de condutas, com prestação de uma parte e contraprestação de outra.

Divide-se, portanto, a onerosidade em duas, criando critérios sobre a previsibilidade da contraprestação: se há certeza quanto o que será pago em retribuição, a figura é da comutatividade; se há variabilidade envolvida na contraprestação, existirá aleatoriedade ${ }^{12}$.

Convém, ainda, o registro de que os negócios jurídicos podem ser neutros ou bifrontes. No primeiro caso (neutro), é irrelevante o viés contraprestacional para caracterizar o negócio, como se pode depreender, de forma exemplificativa, do casamento ${ }^{13}$ e da instituição de cláusula de incomunicabilidade, impenhorabilidade e inalienabilidade.

No caso do bifronte, a presença, ou não, de onerosidade deve ser dirimida e analisada no caso concreto, por ser possível que um negócio jurídico, seja ou oneroso ou gratuito, tal como o mandato e o depósito, por exemplo.

Pois bem, é fato que a manifestação de vontade pode ser aduzida pela parte, pessoalmente, ou pode ser, por vezes, suscitada através de um representante (legal, nos moldes do artigo $37^{14}$;

\footnotetext{
${ }^{12}$ No que pertine à sorte (álea), impossível não fazer referência à famosa frase de Caio Júlio César, proferida ao atravessar o Rio Rubicão com suas legiões e que iniciou a Segunda Guerra Civil da República Romana: alea jacta est (a sorte está lançada).

${ }^{13}$ Faço o registro pessoal, eis que, a despeito da norma portuguesa e de, virtualmente, toda a doutrina conhecida, o casamento, em verdade, não é contrato, tampouco negócio jurídico, por lhe faltar manifesto viés negocial, essencial para caracterizar qualquer negócio jurídico.
}

${ }^{14}$ ARTIGO $37^{\circ}$ (Representação legal)

A representação legal está sujeita à lei reguladora da relação jurídica de que nasce o poder representativo. 
orgânico, à luz do artigo $38^{15} 16$; ou voluntário, ante o teor do art. $39^{17}{ }^{18}$ ). Assim, graficamente, tem-se um negócio jurídico ${ }^{19}$ de A (representado), devidamente representado por

\section{${ }^{15}$ ARTIGO 38 (Representação orgânica)}

A representação da pessoa colectiva por intermédio dos seus órgãos é regulada pela respectiva lei pessoal.

${ }^{16}$ É curioso que a legislação portuguesa, como se depreende dos artigos 38 e 39, optou por distinguir a representação voluntária, decorrente de negócio jurídico prévio, celebrado entre representante e representado, da representação orgânica, que é aquela que define que haverá um órgão com atribuição de representar uma pessoa colectiva. No Brasil, infelizmente, não há a referida distinção, sendo que a normatização trata todos os fenômenos de igual forma. Pontes de Miranda, já em 1973, criticava a opção legislativa da não distinção, assinalando que a representacão (voluntária ou legal) seria distinta da presentacão, figura similar à representação orgânica lusitana. Segue o ensinamento do nobre doutrinador alagoano:

"Órgão e Presentação - Conforme temos sempre frisado, chamando atenção para as graves confusões que aparecem em leis e em livros, indiferentes à terminologia indispensável à expressão das leis e às exposições do direito, onde há órgão não há representação, nem procuração, nem mandato, nem qualquer outra outorga de poderes. o órgão é parte do ser, como acontece às entidades jurídicas, ao próprio homem e as animais. Coração é órgão, fígado é órgão, olhos são órgãos; o Presidente da República é órgão; o Governador de Estado-membro e o Prefeito são órgãos. Quando uma entidade social, que se constitui, diz qual pessoa que por ela figura nos negócios jurídicos e nas atividades com a Justiça, aponta-a como o seu órgão, que pode presentá-la (isto é, estar presente para dar presença à entidade de que é órgão) e, conforme a lei ou os estatutos, outorgar poderes a outrem, que então representa a entidade." (PONTES DE MIRANDA, Francisco Cavalcanti - Comentários ao Código de Processo Civil - Tomo I. Rio de Janeiro: Forense, 1973, pags. 318/319.

\section{${ }^{17}$ ARTIGO 39 $^{\circ}$ (Representação voluntária)}

1. A representação voluntária é regulada, quanto à existência, extensão, modificação, efeitos e extinção dos poderes representativos, pela lei do Estado em que os poderes são exercidos.

2. Porém, se o representante exercer os poderes representativos em país diferente daquele que o representado indicou e o facto for conhecido do terceiro com quem contrate, é aplicável a lei do país da residência habitual do representado.

3. Se o representante exercer profissionalmente a representação e o facto for conhecido do terceiro contratante, é aplicável a lei do domicílio profissional.

4. Quando a representação se refira à disposição ou administração de bens imóveis, é aplicável a lei do país da situação desses bens.

${ }^{18}$ A representação voluntária, por sua vez, é deflagrada ao mundo dos fatos através da procuração, como expresso no artigo 262, verbis:

\section{DIVISÃO II \\ Representação voluntária \\ ARTIGO 262 (Procuração)}

1. Diz-se procuração o acto pelo qual alguém atribui a outrem, voluntariamente, poderes representativos.

2. Salvo disposição legal em contrário, a procuração revestirá a forma exigida para o negócio que o procurador deva realizar.

${ }^{19}$ Como se sabe, é translúcido que, para a celebração de negócios jurídicos, há a necessidade de agente capaz que venha a manifestar a sua declaração de vontade, que pode ser feita de forma expressa ou tácita, nos ditames do artigo 217:

ARTIGO 217

(Declaração expressa e declaração tácita)

1. A declaração negocial pode ser expressa ou tácita: é expressa, quando feita por palavras, escrito ou qualquer outro meio directo de manifestação da vontade, e tácita, quando se deduz de factos que, com toda a probabilidade, a revelam.

2. O carácter formal da declaração não impede que ela seja emitida tacitamente, desde que a forma tenha sido observada quanto aos factos de que a declaração se deduz. 
b (representante), celebrado com C (declaratário da manifestação de vontade de A), demonstrado da seguinte forma:

Fig. 4 - Demonstração da Representação

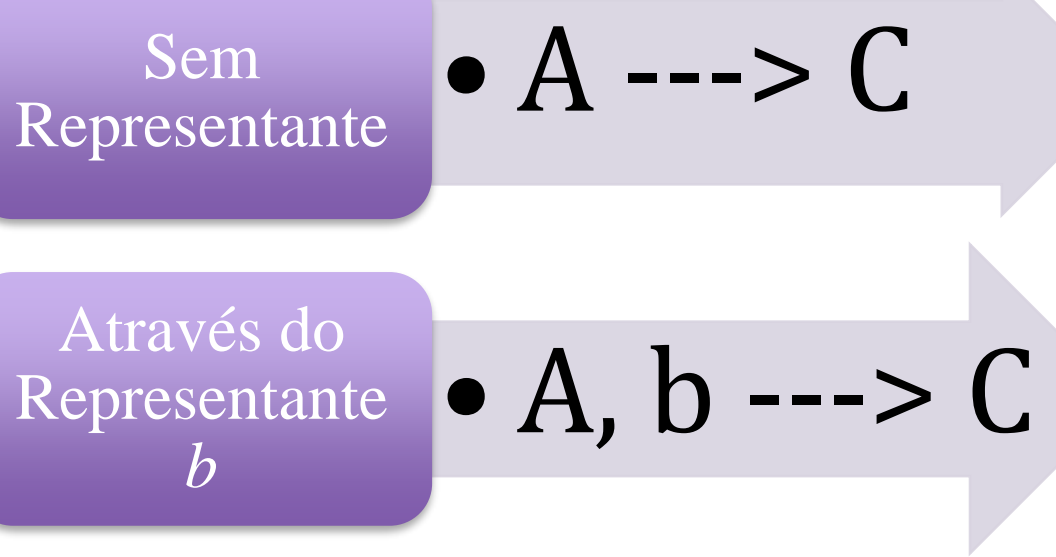

Fonte: DELLA NINA, Pedro Linhares (2020)

A presunção relativa existente na normatização, fundamental para a juridicidade das modalidades de representação, considera que a manifestação de vontade, necessária aos negócios jurídicos (sejam os unilaterais ou bilaterais) e aduzida, materialmente, pelo representante, demonstra o próprio desejo do representado, nos limites dos poderes outorgados, Essa é a regra de ouro para a validade de toda e qualquer representação, estando esculpida no artigo 258, do CC lusitano ${ }^{20}$ :

\section{ARTIGO 258 \\ (Efeitos da representação)}

O negócio jurídico realizado pelo representante em nome do representado, nos limites dos poderes que lhe competem, produz os seus efeitos na esfera jurídica deste último.

\section{Da vedação ao negócio consigo mesmo e do mandato sem representação}

Há, ainda, uma digressão fundamental ao presente trabalho: é evidente e inequívoco que, quando o ordenamento jurídico veda a celebração do auto negócio (ou negócio consigo mesmo), não se quer impedir que alguém contrate com si próprio, o que só seria explicado pela psicanálise, através do estudo da multipersonalidade do indivíduo (transtorno dissociativo de identidade). Não faz qualquer sentido que exista uma vedação expressa na norma, proibindo,

${ }^{20}$ Há norma similar no direito brasileiro, como se apura do artigo 116, do CC/BR:

Art. 116. A manifestação de vontade pelo representante, nos limites de seus poderes, produz efeitos em relação ao representado. 
por exemplo, que eu venda para mim mesmo, ou, por absurdo, que eu me outorgue procuração $^{21}$.

Não é esse o espírito ${ }^{22}$ da vedação ao auto negócio, como é óbvio ululante ${ }^{23}$.

O que o ordenamento jurídico busca impedir, quando da proibição do negócio consigo próprio, é que o representante, em nome do representado, firme negócio com o representante, o que, genericamente, poderia gerar conflitos. Essa é a essência do artigo 261, do CC/PT ${ }^{24}$, que cria hipótese de perda de validade do negócio confeccionado, ante a sanção da anulabilidade:

\section{ARTIGO 261 \\ (Negócio consigo mesmo)}

1. É anulável o negócio celebrado pelo representante consigo mesmo, seja em nome próprio, seja em representação de terceiro, a não ser que o representado tenha especificadamente consentido na celebração, ou que o negócio excluía por sua natureza a possibilidade de um conflito de interesses.

2. Considera-se celebrado pelo representante, para o efeito do número precedente, o negócio realizado por aquele em quem tiverem sido substabelecidos os poderes de representação.

A vedação, como não poderia deixar de ser, até pela origem romana do ordenamento civil, também consta da norma brasileira, penalizando, no plano da validade, com a anulabilidade do negócio jurídico:

Art. 117. Salvo se o permitir a lei ou o representado, é anulável o negócio jurídico que o representante, no seu interesse ou por conta de outrem, celebrar consigo mesmo.

É fácil perceber que a vedação ao autocontrato, firmado pelo representado, através do representante, que se contrata a si própria (perdoe-me pelo pleonasmo literário), é norma geral, podendo ser excepcionada, sendo esse o cerne do presente relatório. O contrato de Mandato sem Representação, previsto nos já transcritos artigos 1.180 ao 1.184, do Código Civil Português, é, exatamente, o instrumento jurídico para que o representante, na defesa dos seus próprios interesses, possa, em nome do representado, celebrar contrato consigo mesmo.

\footnotetext{
${ }^{21}$ O que não deve ser confundido com advogar em causa própria. É translúcido que o advogado detém a capacidade postulatória, podendo ser parte, ativa ou passiva, de um processo judicial. Embora não seja profissionalmente recomendado, resta claro que o advogado poderá ser seu próprio representante judicial, inexistindo razão para que formalize, através de instrumento procuratório, a outorga de poderes para si próprio, o que seria uma excrescência jurídica.

${ }^{22}$ Parafraseando Montesquieu, em sua genial obra De l'esprit des lois.

${ }^{23}$ Em referência ao não menos genial Nelson Rodrigues, jornalista e escritor brasileiro, nascido em Pernambuco, mas Fluminense de coração.

${ }^{24}$ Curioso é que, em Portugal, no Código Civil anterior (Código de Seabra), não havia qualquer normatização, sendo fruto inovador do Código atual (Decreto-Lei n. ${ }^{\circ} 47.344$, de 25/11/1966).
} 
Há diversas definições do instituto na doutrina portuguesa, como se depreende dos dois exemplos a seguir transcritos, que atingem e esclarecem o ponto nodal e conceituam o mandato sem representação:

\begin{abstract}
"De acordo com o disposto no art. $1180^{\circ} \mathrm{CC}$, o mandatário, se agir em nome próprio, adquire os direitos e assume as obrigações decorrentes do acto que celebra.

O que caracteriza o mandato sem representação, é o facto de o mandatário agir em seu nome próprio.

Em vez, assim, de os actos produzirem os seus efeitos na esfera jurídica do mandante (art. $258^{\circ} \mathrm{CC}$ ), produzem-nos na esfera do mandatário. No fundo, o alcance da actuação em nome próprio é o de fazer projectar sobre a esfera jurídica do agente, além dos efeitos característicos da situação de parte, os de natureza pessoal: é ele quem tem legitimidade para exigir e receber o cumprimento das obrigações decorrentes do contrato, é contra ele que a outra parte se deve dirigir, não só para reclamar os seus créditos como para fazer valer quaisquer acções pessoais derivadas do contrato, nomeadamente a respeitante à sua validade ou eficácia.” 25
\end{abstract}

"Conforme o art. $1180{ }^{\circ}$ do Cód. Civil, no mandato sem representação, o mandatário age em nome próprio, adquire os direitos e assume as obrigações decorrentes dos actos que celebra.

Segundo a tese da dupla transferência, adoptada pelo legislador no âmbito do mandato para adquirir (art. 1180. ${ }^{\circ}$ do Cód. Civil), os efeitos repercutem-se na esfera do mandatário, sendo necessário um negócio autónomo para os transmitir para o mandante. Este, por seu turno, é obrigado a fornecer ao mandatário os meios necessários à execução do mandato, entre os quais se encontra a provisão para despesas (art. 1167. ${ }^{\circ}$, al a), do Cód. Civil). Como os direitos adquiridos em execução do mandato são primeiramente imputados à esfera de pertinência do mandatário, o preceito do art. 1181. ${ }^{\circ}$ do Cód. Civil impõe-lhe a obrigação de os transferir para o mandante." 26

No Brasil, há o mesmo instituto, denominado de Procuração em Causa Própria, previsto no artigo 685, do CC/BR, que é rigorosamente idêntico, na essência, ao mandato sem representação português. Segue o comando legal brasileiro:

Art. 685. Conferido o mandato com a cláusula "em causa própria", a sua revogação não terá eficácia, nem se extinguirá pela morte de qualquer das partes, ficando o mandatário dispensado de prestar contas, e podendo transferir para si os bens móveis ou imóveis objeto do mandato, obedecidas as formalidades legais.

E, da doutrina brasileira, há excelentes definições sobre a aludida procuração em causa própria que, por simetria, podem ser aplicadas ao instituto jurídico objeto do presente relatório:

\footnotetext{
25 ALBERTO, Octávio Manuel Gomes. Público [Em linha]. Disponível em http://octalberto.no.sapo.pt/contrato_de_mandato.htm [Consult. 30 outubro 2020].

${ }^{26}$ VAZ TOMÉ, Maria João Romão Carreiro - Sobre o contrato de mandato sem representação e o trust. Público $\quad[$ lem $\quad$ linha $] . \quad$ Disponível em http://www.oa.pt/Conteudos/Artigos/detalhe_artigo.aspx ?idsc=65580\&ida=65532 [Consult. 30 outubro 2020].
} 
"Normalmente, o mandato em causa própria está inserido em outras relações negociais nas quais o mandante já teve esvaziado todo o seu interesse jurídico e, por isso, concede a um terceiro poderes para plenamente atuar em seu nome. Enfim, são negócios celebrados no interesse exclusivo do outorgado, correspondendo, via de regra, a situação jurídica em que o outorgante já viu os seus fins plenamente realizados. Subjacente ao contrato de mandato em causa própria, são localizáveis, frequentemente, outros negócios (contratos atípicos ou contratos interligados). Assim, como os fins almejados pelo outorgante já foram atendidos, conferem-se poderes ao mandatário para, dali em diante, atuar em seu próprio interesse." 27

"O mandato ou procuração em causa própria (in rem suam) é uma exceção à vedação do autocontrato.

Sua utilização é extremamente comum para a celebração de contratos de compra e venda, com o fito de facilitar a transmissão da propriedade, evitando a necessidade da 'presença física' do alienante, admitindo-se a sua 'presença jurídica' por meio do mandatário, que é o principal interessado no cumprimento do negócio.

Assim, a procuração em causa própria é estabelecida no interesse exclusivo do mandatário, que recebe poderes para desempenhar o mandato, com a transmissão de bem de titularidade do mandante em seu favor (...)." 28

A característica principal do mandato sem representação, que o distingue daquele com representação (representação contratual normal, em que o outorgado age em nome do outorgante, para defender os interesses do próprio outorgante - artigos 1.1178 e $1.179^{29}$ ), decorre dos seus efeitos e dos desmembramentos jurídicos, principalmente na fase pós celebração. É fato que, no exercício de direito potestativo, a regra é que o mandante pode revogar o instrumento de representação a qualquer tempo, por se tratar de um negócio jurídico que tem imbuído o elemento da fidúcia, de confiança, em relação ao mandatário.

\footnotetext{
${ }^{27}$ DE FARIAS, Cristiano Chaves; ROSENVALD, Nelson - Curso de Direito Civil vol. 4 - Contratos. $3^{\mathrm{a}}$ ed. Salvador: Editora Juspodium, 2013, pag. 924.

${ }^{28}$ GAGLIANO, Pablo Stolze; PAMPLONA, Rodolfo - Novo Curso de Direito Civil vol. 4, tomo 2 - Contratos em Espécie. $3^{\text {a }}$ ed. São Paulo: Editora Saraiva, 2010, pag. 387.
}

${ }^{29}$ Seguem os dispositivos em comento:

\section{SECÇÃO V \\ Mandato com representação}

\section{ARTIGO 1178 \\ (Mandatário com poderes de representação)}

1. Se o mandatário for representante, por ter recebido poderes para agir em nome do mandante, é também aplicável ao mandato o disposto nos artigos $258^{\circ}$ e seguintes.

2. O mandatário a quem hajam sido conferidos poderes de representação tem o dever de agir não só por conta, mas em nome do mandante, a não ser que outra coisa tenha sido estipulada.

\section{ARTIGO 1179}

(Revogação ou renúncia da procuração)

A revogação e a renúncia da procuração implicam revogação do mandato. 
Porém, como no mandato sem representação, o representante (outorgado/mandatário) age em seu nome, na defesa de seus direitos, não há como permitir que o representado (outorgante/mandante) mantenha a liberdade de revogar a procuração, o que inviabilizaria o negócio jurídico como um todo e a razão de ser do instituto. Assim, como não poderia deixar de ser, o legislador português positivou a figura da irrevogabilidade do mandato sem representação, excepcionando as hipóteses de justa causa, como se apura do item 2, do art. $1.170^{30}$ :

\title{
ARTIGO 1170 \\ (Revogabilidade do mandato)
}

1. O mandato é livremente revogável por qualquer das partes, não obstante convenção em contrário ou renúncia ao direito de revogação.

2. Se, porém, o mandato tiver sido conferido também no interesse do mandatário ou de terceiro, não pode ser revogado pelo mandante sem acordo do interessado, salvo ocorrendo justa causa.

Pedro Pais de Vasconcelos esclarece que a procuração somente poderia ser revogada por quem possui interesse. Como a procuração em causa própria (mandato sem representação) teria como principal interessado o representante, não haveria como permitir que o representado tivesse a liberalidade de revogá-la.

\begin{abstract}
"A fundamentação da irrevogabilidade da procuração reside (...) no princípio segundo o qual os poderes atribuídos no interesse de uma pessoa só podem ser revogados por essa mesma pessoa." 31
\end{abstract}

Existe relevante precedente do Tribunal da Relação de Lisboa que, com clareza, enfrenta e explica a questão, como se depreende do sumário (ementa) abaixo:

"I - O mandato sem representação é o contrato pelo qual uma pessoa (mandante) confia a outra (mandatário) a realização, em nome desta mas no interesse e por conta daquela, de um acto jurídico relativo a interesses pertencentes à primeira, assumindo a segunda a obrigação de praticar esse acto.

II- Opõe-se ao mandato com representação, sendo que neste o mandante conferiu poderes de representação ao mandatário, pelo que este tem o dever de agir, não só por conta, mas também em nome do mandante, a não ser que outra coisa tenha sido estipulada (art 1178\%).

\footnotetext{
${ }^{30}$ A legislação lusitana, extremamente legalista e redundante, repete a regra no item 3, do art. 256, ao versar sobre extinção do instrumento que materializa a representação (a procuração - art. 262), verbis:
}

\section{ARTIGO 265}

(Extinção da procuração)

1. A procuração extingue-se quando o procurador a ela renuncia, ou quando cessa a relação jurídica que lhe serve de base, excepto se outra for, neste caso, a vontade do representado.

2. A procuração é livremente revogável pelo representado, não obstante convenção em contrário ou renúncia ao direito de revogação.

3. Mas, se a procuracão tiver sido conferida também no interesse do procurador ou de terceiro, não pode ser revogada sem acordo do interessado, salvo ocorrendo justa causa.

${ }^{31}$ DE VASCONCELOS, Pedro Pais - Procuração Irrevogável. Coimbra: Almedina, 2002, pag. 111. 
III -Não modifica a natureza ao mandato sem representação a circunstância do terceiro com quem contrata o mandatário ter conhecimento da pessoa por conta de quem este age, embora seja lícito ao mandatário sem representação ocultar junto do mesmo, se for do seu interesse, a sua posição em relação ao mandante.

IV - O mandatário que age em nome próprio fica sendo titular dos direitos adquiridos em execução do mandato, sendo já num segundo momento que, e, em cumprimento das suas obrigações contratuais com o mandante, deve transferir para este a titularidade desses direitos. Se adquiriu coisas, deve entregá-las ao mandante, transferindo simultaneamente os respectivos direitos reais; se adquiriu créditos, deve cedê-los.

$\mathrm{V}$ - $\mathrm{O} \mathrm{n}^{\circ} 2$ do art $1181^{\circ}$ confirma, em relação aos créditos, a tese de que a execução do mandato sem representação produz os seus efeitos na esfera do mandatário e não do mandante, pois só assim se compreende a possibilidade da substituição: o direito é do mandatário, enquanto não for transferido."

(Apelação no processo n. ${ }^{\circ}$ 448/07.0TBRMR.L1-2, relatado pela juíza Teresa Albuquerque, julgado em 17/12/2014, por unanimidade)

E, como se não bastasse o diferencial da irrevogabilidade do negócio jurídico, o curioso é que nem a morte do mandante extinguiria os efeitos do mandato sem representação, pois ainda assim persistiria (mesmo após o óbito do mandante, repita-se) o interesse do negócio por parte do mandatário. Esse é o teor do art. 1.175:

\section{ARTIGO 1175 \\ (Morte, interdição ou inabilitação do mandante)}

A morte, interdição ou inabilitação do mandante não faz caducar o mandato, quando este tenha sido conferido também no interesse do mandatário ou de terceiro; nos outros casos, só o faz caducar a partir do momento em que seja conhecida do mandatário, ou quando da caducidade não possam resultar prejuízos para o mandante ou seus herdeiros.

Os efeitos do mandato sem representação, no que se refere ao falecimento do mandante e da irrevogabilidade do instrumento, são rigorosamente os mesmos no Código Civil Brasileiro, ante a clareza do sucinto e objetivo artigo 685 (já transcrito). O Superior Tribunal de Justiça tem paradigmal precedente sobre a impossibilidade de a procuração em causa própria perder a eficácia após a morte do mandante:

"Civil e Processo Civil. Ação de imissão na posse. Direitos hereditários. procuração em causa própria. Contrato distinto do mandato tradicional. Transferência de direitos. Morte do promitente-vendedor. Irrelevância. Validade do instrumento. Doutrina. Jurisprudência. Recurso provido.

i - Pelo contrato de mandato em causa própria, o mandante transfere todos os seus direitos sobre um bem, móvel ou imóvel, passando o mandatário a agir por sua conta, em seu próprio nome, deixando de ser uma autorização, típica do contrato de mandato, para transformar-se em representação.

ii - Ao transferir os direitos, o mandante se desvincula do negócio, não tendo mais relação com a coisa alienada, pelo que não há que se falar em extinção do contrato pela morte do mandante. O contrato permanece válido e, em consequência, a procuração, que e sua forma, mesmo depois do decesso do vendedor. 
iii - Esse posicionamento, ademais, ajusta-se ao entendimento segundo o qual a promessa de compra-e-venda somente reclama inscrição do instrumento para sua validade e eficácia perante terceiros, mostrando-se hábil a obtenção da adjudicação compulsória em relação ao promitente vendedor independentemente desse registro."

(Recurso Especial n. ${ }^{\circ}$ 64.457, da $4^{\text {a }}$ Turma do STJ, julgado em 08/10/1997, relatado pelo Ministro Sálvio de Figueiredo Teixeira).

Por fim, após explanar, ainda que brevemente, sobre o mandato com representação e o mandato sem representação - o último que é o cerne do presente trabalho -, é de se concluir a trifeta (hat-trick) da representação no direito português, discorrendo sobre a gestão de negócios que, nada mais é, do que a representação sem o mandato, isto é, sem negócio jurídico prévio. Seguem a integra dos artigos 464 a 472 , do CC/PT ${ }^{32}$ :

\section{SECÇÃO III \\ Gestão de negócios}

\section{ARTIGO 464" \\ (Noção)}

Dá-se a gestão de negócios, quando uma pessoa assume a direção de negócio alheio no interesse e por conta do respectivo dono, sem para tal estar autorizada.

\section{ARTIGO 465 \\ (Deveres do gestor) \\ O gestor deve:}

a) Conformar-se com o interesse e a vontade, real ou presumível, do dono do negócio, sempre que esta não seja contrária à lei ou à ordem pública, ou ofensiva dos bons costumes;

b) Avisar o dono do negócio, logo que seja possível, de que assumiu a gestão;

c) Prestar contas, findo o negócio ou interrompida a gestão, ou quando o dono as exigir;

d) Prestar a este todas as informações relativas à gestão;

e) Entregar-lhe tudo o que tenha recebido de terceiros no exercício da gestão ou o saldo das respectivas contas, com os juros legais, relativamente às quantias em dinheiro, a partir do momento em que a entrega haja de ser efectuada.

\section{ARTIGO 466 ${ }^{\circ}$ \\ (Responsabilidade do gestor)}

1. O gestor responde perante o dono do negócio, tanto pelos danos a que der causa, por culpa sua, no exercício da gestão, como por aqueles que causar com a injustificada interrupção dela.

\footnotetext{
$32 \mathrm{O}$ instituto também está presente na codificação brasileira, com o mesmo nomen iuris de Gestão de Negócio. Deve-se aclarar na presente nota que a norma do Brasil aproxima o instituto ao mandato, pois, caso o interessado venha a ratificar o que foi feito pelo gestor, aplicar-se-ão as regras da representação. Seguem os artigos 861 e 873 : Art. 861. Aquele que, sem autorização do interessado, intervém na gestão de negócio alheio, dirigi-lo-á segundo o interesse e a vontade presumível de seu dono, ficando responsável a este e às pessoas com que tratar.
}

Art. 873. A ratificação pura e simples do dono do negócio retroage ao dia do começo da gestão, e produz todos os efeitos do mandato. 
2. Considera-se culposa a actuação do gestor, quando ele agir em desconformidade com o interesse ou a vontade, real ou presumível, do dono do negócio.

\section{ARTIGO $467^{\circ}$ \\ (Solidariedade dos gestores)}

Havendo dois ou mais gestores que tenham agido conjuntamente, são solidárias as obrigações deles para com o dono do negócio.

\section{ARTIGO 468 \\ (Obrigações do dono do negócio)}

1. Se a gestão tiver sido exercida em conformidade com o interesse e a vontade, real ou presumível, do dono do negócio, é este obrigado a reembolsar o gestor das despesas que ele fundadamente tenha considerado indispensáveis, com juros legais a contar do momento em que foram feitas, e a indemnizá-lo do prejuízo que haja sofrido.

2. Se a gestão não foi exercida nos termos do número anterior, o dono do negócio responde apenas segundo as regras do enriquecimento sem causa, com ressalva do disposto no artigo seguinte.

\section{ARTIGO 469}

(Aprovação da gestão)

A aprovação da gestão implica a renúncia ao direito de indemnização pelos danos devidos a culpa do gestor e vale como reconhecimento dos direitos que a este são conferidos no n. $^{\circ} 1$ do artigo anterior.

\section{ARTIGO 470 \\ (Remuneração do gestor)}

1. A gestão não dá direito a qualquer remuneração, salvo se corresponder ao exercício da actividade profissional do gestor.

2. À fixação da remuneração é aplicável, neste caso, o disposto no n. ${ }^{\circ} 2$ do artigo $1158^{\circ}$.

\section{ARTIGO 471}

(Representação sem poderes e mandato sem representação)

Sem prejuízo do que preceituam os artigos anteriores quando às relações entre o gestor e o dono do negócio, é aplicável aos negócios jurídicos celebrados por aquele em nome deste o disposto no artigo $268^{\circ}$; se o gestor os realizar em seu próprio nome, são extensivas a esses negócios, na parte aplicável, as disposições relativas ao mandato sem representação.

\section{ARTIGO 472 \\ (Gestão de negócio alheio julgado próprio)}

1. Se alguém gerir negócio alheio, convencido de que ele lhe pertence, só é aplicável o disposto nesta secção se houver aprovação da gestão; em quaisquer outras circunstâncias, são aplicáveis à gestão as regras do enriquecimento sem causa, sem prejuízo de outras que ao caso couberem.

2. Se houver culpa do gestor na violação do direito alheio, são aplicáveis ao caso as regras da responsabilidade civil.

De todas as definições do instituto denominado gestão de negócios, convém transcrever os ensinamentos provenientes da obra Inocêncio Galvão Telles que, como a sua acurácia conceitual, assevera que: 
"Por vezes uma pessoa, sem ter recebido do interessado poderes de representação, celebra em nome dele um contrato. Verdadeiramente, procede como simples gestor de negócios, quer invoque esta qualidade, quer a qualidade que não possui, de representante." 33

Da parte brasileira, é de vital importância rememorar as lições do mestre Silvio Rodrigues que, ainda no Código de 1916, demonstrava a real função da gestão de negócios:

"Já verificamos que o mandatário que excede os poderes do mandato atua como gestor de negócios. Essa, de fato, a idéia de gestão de negócios. Ela ocorre quando alguém age em nome de outrem, sem ter mandato para tal. Ou, no conceito de COELHO DA ROCHA (Instituições, v. II, §800), a gestão é a administração voluntária de negócios alheios, feita sem procuração.

Trata-se, no mais das vezes, de um ato de altruísmo, em que o gesto, com intuito de evitar um prejuízo para o dono do negócio, porventura ausente, embora sem estar por ele autorizado, ou pela lei, toma a iniciativa de intervir na órbita de interesses daquele, para preservá-los, atuando como atuaria o dono da coisa, se ali estivesse." ${ }^{34}$

\section{Conclusão}

Com isso posto, vê-se que o contrato denominado Mandato sem Representação, previsto nos artigos 1.180 ao 1.184 , do Código Civil Português, é negócio jurídico relevante, com extrema aplicabilidade nas situações atuais, traçando evidente paralelo com a procuração em causa própria brasileira.

\section{REFERÊNCIAS}

ALBERTO, Octávio Manuel Gomes. Público [Em linha]. Disponível em http://octalberto.no.sapo.pt/contrato_de_mandato.htm [Consult. 30 outubro 2020].

COELHO, Fabio Ulhoa - Curso de Direito Civil Parte Geral - Vol. 1. $8^{\text {a }}$ ed. São Paulo: Revista dos Tribunais, 2016. ISBN 978-85-203-6684-4

DE FARIAS, Cristiano Chaves; ROSENVALD, Nelson - Curso de Direito Civil vol. 4 Contratos. $3^{\text {a }}$ ed. Salvador: Editora Juspodium, 2013

DE VASCONCELOS, Pedro Pais - Procuração Irrevogável. Coimbra: Almedina, 2002

\footnotetext{
${ }^{33}$ TELLES, Inocêncio Galvão - Manual dos Contratos em Geral. 4ª ed. Coimbra: Coimbra Editora, pag. 435.

34 RODRIGUES, Silvio - Direito Civil - Volume 3 - Dos Contratos e das Declarações Unilaterais de vontade. $27^{\mathrm{a}}$ ed. Rio de Janeiro: Editora Saraiva, pag. 292.
} 
DOMINGUES DE ANDRADE, Manuel A. - Teoria Geral da Relação Jurídica - vol. 1. $1^{\text {a }}$ ed. Coimbra: Almedina, 1983. ISBN 978-97-240-04259

GAGLIANO, Pablo Stolze; PAMPLONA, Rodolfo - Novo Curso de Direito Civil, vol. 4, tomo 2 - Contratos em Espécie. $3^{\mathrm{a}}$ ed. São Paulo: Editora Saraiva, 2010.

GRAU, Eros Roberto - Um Novo Paradigma dos Contratos?. Público [Em linha]. [Consult. 30 outubro. 2020]. Disponível em http://www.revistas.usp.br/rfdusp/article/view/67510

NADER, Paulo - Curso de Direito Civil Vol. 1. $10^{\mathrm{a}}$ ed. Rio de Janeiro: Forense, 2016. ISBN 978-85-309-6355-2

PONTES DE MIRANDA, Francisco Cavalcanti - Comentários ao Código de Processo Civil

- Tomo I. Rio de Janeiro: Forense, 1973

RODRIGUES, Silvio - Direito Civil - Volume 3 - Dos Contratos e das Declarações Unilaterais de vontade. $27^{\mathrm{a}}$ ed. Rio de Janeiro: Editora Saraiva

TELLES, Inocêncio Galvão - Manual dos Contratos em Geral. 4ª ed. Coimbra: Coimbra Editora

VAZ TOMÉ, Maria João Romão Carreiro - Sobre o contrato de mandato sem representação e o trust. Público [Em linha].Disponível em http://sww.oa.pt/Conteudos/Artigos/detalhe_artigo.aspx?idsc $=65580 \& i d a=65532$ [Consult. 30 outubro 2020]. 